\title{
Prevention of relapse in ulcerative colitis using oral or topical 5-aminosalicylic acid therapy
}

\author{
LLOYD R SUTHERLAND, MDCM, MSC, FRCPC, FACP
}

LR SUTHERLAND. Prevention of relapse in ulcerative colitis using oral or topical 5-aminosalicylic acid therapy. Can J Gastroenterol 1993:7(2):232 236. Since ulcerative colitis as a clinical entity can be characterized by its propensity for recurrence or relapse, it should not be surprising that attention has focused on altering the frequency of episodes of colitis. Foremost among the strategies has been the initial assessment and subsequent use of 5 -aminosalicylic acid (5-ASA) preparations for maintaining remission. Aside from the introduction of corticosteroids, no other innovation in therapy has had greater impact for patient quality of life. Probably more 5-ASA preparations are used for maintenance than for induction of remission. There are numerous trials of varying quality which have assessed the use of different oral preparations of 5-ASA, including sulphasalazine, in maintaining remission. The early trials using sulphasalazine suggested a $75 \%$ reduction in relapses for patients taking medication. Recent trials have generally compared the newer 5-ASA oral preparations with sulphasalazine. The efficacy of topical therapy (enemas and suppositories), already demonstrated to be effective in the treatment of active distal disease, has also been demonstrated for maintenance of remission. Questions remain as to the frequency of administration and dose required. Other issues include the possibility of intermittent 5-ASA for maintenance of remission and whether or not there are alternatives for the 5-ASA sensitive patient.

Key Words: 5-Aminosalicylic acid, Oral therapy, Recurrence, Topical therapy, Ulcerative colitis

\section{Prévention de la rechute de la colite ulcéreuse à l'aide d'un traitement oral ou topique au 5-AAS}

RÉSUMÉ: Étant donné que la colite ulcéreuse comme entité clinique peut être caractérisée par sa propension pour les récidives ou les rechutes, il ne faut pas se surprendre que l'on consacre temps et énergie à altérer la fréquence des épisodes de colite. Parmi les stratégies à l'essai, notons l'évaluation initiale et le recours subséquent aux préparations de 5-AAS (acide 5-aminosalicylique) dans le maintien de la rémission. A part l'introduction des corticostéroïdes, aucune innovation thérapeutique n'a eu d'impact plus grand sur la qualité de vie des patients. Les préparations de 5-AAS sont probablement davantage utilisées pour le traitement d'entretien que pour l'induction de la rémission. De nombreux essais de

Department of Medicine, University of Calgary, Calgary, Alberta

Correspondence: Dr Lloyd R Sutherland, Room 1751, 3330 Hospital Dr NW, Calgary,

Alberta, T2N 4N1. Telephone (403) 220-4500, Fax (403) 283-3028
The THERAPY OF ULCERATIVE 1 colitis was advanced by the intro. duction of three strategies: the use of corticosteroids for severe disease; the use of 5-aminosalicylic acid (5-ASA) containing preparations for the maintenance of remission; and the development of sphincter saving procedures when surgery is required. The natural history of recurrence before the introduction of 5-ASA is reviewed here and clinical predictors of recurrence identified. The major clinical trials of maintenance therapy for both oral and topical 5-ASA are summarized and alternate strategies, including intermittent 5-ASA therapy, as well as alternatives to 5-ASA discussed.

\section{NATURAL HISTORY OF RECURRENCE}

Ulcerative colitis has typically been characterized by inevitable recurrent episodes of symptoms. In fact the occurrence of a single attack of 'colitis' in the remote past with no further recurrence is often used as evidence that the attack probably was due to infectious causes rather than ulcerative colitis. In their review of 250 new cases of ulcerative colitis seen at the Radcliffe Infirmary between 1938 and 1962, Edwards and Truelove (1) reported a one-year recurrence rate of approximately $80 \%$. The majority of patients in their study were probably not on any form of maintenance therapy as sulphsalazine was 
qualité variable, ont évalué l'utilisation de différentes préparations orales de 5-AAS, y compris la sulphasalazine dans le maintien de la rémission. Les essais initiaux sur la sulphasalazine démontrent une réduction de $75 \%$ des récidives chez les patients qui prennent le médicament. Des essais récents ont comparé les préparations orales de 5-AAS plus récentes avec la sulphasalazine. Le traitement topique (lavement et suppositoire) a déjà démontré son efficacité dans la maladie distale active pour le maintien de la rémission. Des questions demeurent quant à la fréquence de l'administration et la dose requise. D'autres questions concernent la possibilité d'un traitement intermittent au 5-AAS pour le maintien de la rémission et à la mise au point de solutions de rechange chez les patients sensibles au 5-AAS.

not widely used until well into the 1950s. In a population-based study of patients routinely treated with sulphasalazine maintenance therapy, approximately $80 \%$ had a relapse by the end of the second year of follow-up (2).

Meyers and Janowitz analyzed the clinical recurrences in 174 patients randomized to placebo in trials of 5 . ASA for maintenance of remission (3). Their data should be interpreted cautiously because the effect of taking any medication, even a placebo, cannot be dismissed completely. In four trials, each of six months duration, up to $51 \%$ of patients (range 29 to $51 \%$ ) remained in remission. In two trials of maintenance therapy for 12 months, remission was maintained in only $25 \%$ of patients. This figure is a reasonable approximation of the Edwards and Truelove study cited above (1).

\section{RISK FACTORS FOR RECURRENCE}

There are few studies on potential risk factors or markers which would indicate which patients are at greater risk of recurrence. Most reports are retrospective. A recent prospective study of 92 patients with ulcerative colitis in remission currently taking either sulphasalzine or 5-ASA (Asacol; Procter \& Gamble) found that $38 \%$ had a relapse during the next year (4). Patients who relapsed were characterized as being more likely to have had a relapse during the year before entry into the study (97 versus 56\%, $\mathrm{P}<0.001$ ). They were also noted to have been in remission for a shorter period of time compared with those who remained in remission (seven ver- sus 12 months, $\mathrm{P}<0.01)$. The authors did not find any association between recent stressful life events, antibiotic ingestion or upper respiratory tract infections and recurrence. They noted a seasonal variation; the majority of relapses occurred between August and February, with a peak in September and October. Other investigators have reported that many flare-ups of ulcerative colits are associated with upper respiratory tract infection (5).

\section{ORAL 5-ASA AND MAINTENANCE}

The first trial demonstrating that 5-ASA (sulphasalazine) altered the relapse risk was reported by Misiewicz and colleagues. During a 12-month period, 24 of 34 patients (71\%) taking $2 \mathrm{~g} /$ day of sulphasalazine remained in remission compared with nine of 33 placebo-treated patients (27\%) (6). A subsequent study by Dissanayake and Truelove (7) recommended that sulphasalazine therapy be continued indefinitely.

Azad Khan and associates performed a dose ranging study of 1,2 and $4 \mathrm{~g} /$ day sulphasalazine in 170 patients currently in remission (mainly on $2 \mathrm{~g} /$ day) (8). They found significant differences in recurrence related to the dose of 5-ASA given. Although patients given sulphasalazine $4 \mathrm{~g} /$ day had fewer recurrences than those on $2 \mathrm{~g} /$ day, approximately $10 \%$ of patients on the $4 \mathrm{~g} /$ day dose had to withdraw because of side effects. Twenty-one of the 56 patients randomized to 4 g/day sulphasalazine reported adverse reactions. This emphasizes the concept that many side effects associated with sulphasalazine are dose related as the majority of these patients had previously tolerated 2 g/day sulphsalazine.

The mechanism of action by which 5-ASA is effective in maintenance of remission is not clear. Its efficacy in active disease has been related to effects on leukotriene metabolism $(9,10)$, oxygen free radical scavenging (11-13) or other mechanisms not yet described. Two scenarios are possible to explain the role of 5ASA in maintaining remission. One possibility is that 5-ASA is necessary to constantly either suppress the inflammation or scavenge oxygen free radicals when they are produced. The other is that continuous 5-ASA is effective by being present when whatever factor(s) which trigger an acute episode appear(s).

With the knowledge that 5-ASA was the active agent of sulphasalazine $(14,15)$, the next step was to develop different delivery systems for the sul. pha-sensitive patient (16). Using Asacol, Dew was able to continue maintenance therapy with 5-ASA in the majority of previously sulphasalazine intolerant patients. Of interest, $10 \%$ of sulphasalazine intolerant patients were also intolerant to 5-ASA.

Numerous randomized controlled studies demonstrate that the newer 5 . ASA delivery systems (eg, Salofalk, Interfalk; Mesasal, SmithKline Beecham; Dipentum, Kabi Pharmacia; Pentasa, Nordic) are equivalent to sulphasalazine in maintaining remission (17-26). No study, however, has identified a statistically significant difference between the various delivery systems.

\section{TOPICAL 5-ASA AND MAINTENANCE OF REMISSION}

The efficacy of 5-ASA therapy used as an enema in the treatment of ulcerative proctosigmoiditis is well established (27-30). It is also effective when given as a suppository for patients with localized disease (31-33).

Topical therapy can be used to sustain remission (34-37). Sutherland and Martin (34) compared the relapse rate in 29 patients who had already achieved remission using $4 \mathrm{~g}$ 5-ASA enemas. Patients were randomly assigned to either 2 or $4 \mathrm{~g}$ 5-ASA 
enemas taken at bedtime. Sixty-six per cent of patients remained in remission for the next six months. There were no differences in relapse rates between the two groups. Biddle and associates (35) studied 25 patients randomized to either $1 \mathrm{~g}$ 5-ASA enemas (12 patients) or placebo (13 patients). Over the next year only two placebo-treated patients remained in remission ( $15 \%$ ) compared with $75 \%$ in the 5 -ASA group.

D'Arienzo and a group of Italian investigators (37) demonstrated that 5-ASA suppositories ( $400 \mathrm{~g}$ bid) compared with placebo in 30 patients with distal ulcerative proctitis were effective in maintaining remission. Ninety-two per cent of patients on 5-ASA were relapse-free at the end of a year compared with $21 \%$ of placebo-treated patients.

\section{IS THERE A ROLE FOR 'PRN' 5-ASA?}

Since the mode of action of 5-ASA is not known, it is not clear as to whether continuous 5-ASA is required to maintain remission. An alternative hypothesis would be that early treatment of relapse is the key issue and that continuous therapy is effective only because it ensures that 5-ASA is on hand when the colitis flares. Dickinson and associates (38) explored this hypothesis in a clinical trial of $2 \mathrm{~g} /$ day sulphasalazine versus $3 \mathrm{~g}$ sulphasalazine taken at the first sign of relapse. During the trial approximately the same proportion of patients on either treatment regimen relapsed but the statistical power of the trial was low and the possibility of a type II error remains. Rectal biopsies from both treatment groups were reviewed blindly and the pathologist could not differentiate between those patients on continuous 5-ASA and those on intermittent therapy.

D'Albasio and associates (36) compared the efficacy for maintenance of remission for $4 \mathrm{~g}$ 5-ASA enemas taken for the first week of every month compared with $2 \mathrm{~g}$ sulphasalazine taken daily by mouth in 60 patients with distal colitis. A minor criticism would be that the trial was not conducted in a double-dummy fashion. Using lifetable analysis, the investigators demon- strated that the relapse rates were similar for both groups.

\section{IS THERE AN ALTERNATIVE FOR THE 5-ASA SENSITIVE PATIENT?}

Approximately $10 \%$ of patients who report adverse reactions while taking sulphasalazine will also be intolerant to 5-ASA preparations. A variety of alternatives to 5-ASA have been assessed, including corticosteroids $(39-42)$, azathioprine $(43,44)$, metronidazole (45), cromoglycate (46) and levamisole (47). Interpretation of these studies is often difficult as the sample sizes are generally small and the statistical power is low.

Soon after the initial reports that corticosteroids were effective in the therapy of active ulcerative colitis $(39,48)$, a variety of studies assessed the efficacy of steroids for maintenance therapy, given either as an enema twice weekly (39) or taken each day by mouth either as $50 \mathrm{mg}$ cortisone (40) or $15 \mathrm{mg}$ prednisone (41). These trials failed to demonstrate any efficacy for corticosteroids in maintaining remission. Powell-Tuck and associates (42) hypothesized that steroid therapy, if given in a high enough dose, could be effective. They speculated that an alternate day regimen would allow the use of a higher dose of corticosteroid (40 mg prednisolone) and alter the side effect profile. They performed a crossover trial in 31 patients in remission, the majority of whom continued sulphasalazine. Using life table analysis, significant differences in recurrence rates were identified in the 24 patients who completed both treatment cycles. A greater percentage of prednisolonetreated patients remained in remission compared with placebo-treated patients ( $80 \%$ versus $46 \%, 0.05>P>0.02$ ).

Azathioprine has been assessed, generally in combination with corticosteroids, in the treatment of active ulcerative colitis and found to offer little benefit (43). However, Jewell and Truelove, in the maintenance phase of their trial, found fewer relapses in patients with a past history of recurrence who continued on azathioprine $(2.5 \mathrm{~g} / \mathrm{kg})$, but the difference in relapse did not quite reach statistical significance. Hawthorne and colleagues (44) recently reported preliminary results of an azathioprine withdrawal trial for patients thought to have responded to azathioprine. Patients were randomly assigned to continued azathioprine or placebo. Recurrence was reported more frequently for placebo-treated patients compared with those remaining on active therapy ( 56 versus $33 \%, \mathrm{P}=0.04$ ).

Metronidazole is not effective in the treatment of active ulcerative colitis either as monotherapy (49) or adjunctive therapy in combination with corticosteroid (50). Gilat and colleagues (45) compared the efficacy of metronidazole (600 mg daily) and sulphasalazine (2 g/day) in maintaining remission for 12 months. The relapse rate was high in both groups, with 12 of the 15 sulphasalazine-treated patients relapsing compared with 11 of the 20 metronidazole treated patients. Statistically significant differences, however, could be detected using life-table analysis. The study results should be interpreted cautiously as the relapse rate for the sulphasalazine-treated patients was unusually high.

Sodium cromoglycate is effective in type I hypersensitivity reactions, perhaps through its ability to stabilize mast cells. Since mast cells may be important in ulcerative colitis, cromoglycate has been assessed for both active ulcerative colitis and for maintenance of remission. A group of British gastroenterologists compared the remission sustaining properties of cromoglycate in patients stratified by concurrent use of sulphasalazine (46). There was no benefit for the combinabon of sulphasalazine plus cromoglycate compared with sulphasalazine alone. In a small group of patients who were not taking concurrent sulphasalazine (18), fewer relapses occurred on patients randomized to cromoglycate (400 mg qid) compared with placebo-treated patients, but this did not reach statistical significance.

Levamisole has also been assessed as a potential agent for maintenance of remission. In a placebo-controlled, two-year study of this immunostimulant, no difference in relapse rates could be identified (47). 
In conclusion, the use of 5-ASA containing preparations has altered the natural history of ulcerative colitis by prolonging the time in remission. It would appear that the 5-ASA preparations are effective in maintaining remission. Topical therapy is effective and there is preliminary evidence to suggest that intermittent use of 5-ASA may be possible. Alternatives to 5 . ASA for the 5-ASA sensitive patient have not been identified.

\section{REFERENCES}

1. Edwards F, Truelove SC. The course and prognosis of ulcerative colitis II. Long-term prognosis. Gut 1963:4:309-15.

2. Hendriksen C, Kreiner S, Binder V. Long term prognosis in ulcerative colitis - based on results from a regional patient group from the county of Copenhagen. Gut 1985;26:158-63.

3. Meyers S, Janowitz HD. The "natural history" of ulcerative colitis: An analysis of the placebo response. J Clin Gastroenterol 1989;11:33-7.

4. Riley SA, Mani V, Goodman MJ, Lucas S. Why do patients with ulcerative colitis relapse? Gut 1990;31:179-83.

5. Kangro HO, Chong SKF, Hardiman A, Heath RB, Walker-Smith JA. A prospective study of viral and mycoplasma infections in chronic inflammatory bowel disease. Gastroenterology 1990;98:549-53.

6. Misiewicz JJ, Lennard-Jones JE, Connell AM, Baron JH, Jones FA. Controlled trial of sulphasalazine in maintenance therapy for ulcerative colitis. Lancet 1965; i: 185-8.

7. Dissanayake AS, Truelove SC. A controlled therapeutic trial of long-term maintenance treatment of ulcerative colitis with sulphasalazine (Salazopyrin). Gut 1973;14:923-6.

8. Azad Khan AK, Piris J, Truelove SC, Howes DT. An optimum dose of sulphasalazine for maintenance treatment in ulcerative colitis. Gut 1980;21:232-40.

9. Klotz U, Maier K, Fischer C, Heinkel $\mathrm{K}$. Therapeutic efficacy of sulphasalazine and its metabolites in patients with ulcerative colitis and Crohn's disease. N Engl J Med 1980;303:1499-502.

10. Lauritsen K, Laursen L, Bukhave K, Rask-Madsen J. Effects of topical 5-aminosalicylic acid and prednisolone on prostaglandin E2 and leukotriene B4 levels determined by equilibrium in vivo dialysis of rectum in relapsing ulcerative colitis. Gastroenterology 1986;91:837-44.

11. Ahnfelt-Ronne I, Nielsen $\mathrm{OH}$, Christensen A, Langholz E, Binder V, Riis P. Clinical evidence supporting the radical scavenger mechanism of 5 -aminosalicylic acid. Gastroenterology 1990;98:1162-9.

12. Tamai H, Kachur JF, Grisham MB, Gaginella TS. Scavenging effect of 5-aminosalicylic acid on neutrophilderived oxidants. Possible contribution to the mechanism of action in inflammatory bowel disease. Biochem Pharmacol 1991;41:1001-6.

13. Verspaget HW, Aparicio-Pagés MN, Verver S, et al. Influence of sulphasalazine and mesalazine on cellular and biochemical oxygen metabolite production. Effect of in vivo administration and an in vitro analysis. Scand J Gastroenterol 1991;26:779-86.

14. Azad Khan AK, Piris J, Truelove SC. An experiment to determine the active therapeutic moiety of sulphasalazine. Lancet 1977; ii:892-5.

15. Van Hees PAM, Bakker JH, Van Tongeren JHM. Effect of sulphapyridine, 5-aminosalicylic acid and placebo in patients with with idiopathic proctitis: A study to determine the active therapeutic moiety of sulphasalazine. Gut 1980;21:632-5.

16. Dew MJ, Harries AD, Evans BK, Rhodes J. Treatment of ulcerative colitis with oral 5-aminosalicylic acid in patients unable to take sulphasalazine. Lancet 1983;ii:801.

17. McIntrye PB, Rodrigues CA, Lennard-Jones JE, et al. Balsalazide in the maintenance treatment of patients with ulcerative colitis, a double-blind comparison with sulphasalazine. Aliment Pharmacol Therap 1988;2:237-43.

18. Mulder CJJ, Tytgat GNJ, Waterman IT, et al. Double-blind comparison of slow-release 5-aminosalicylate and sulphasalazine in remission maintenance in ulcerative colitis. Gastroenterol 1988;95:1449-53.

19. Jewell DP, Ireland A. Controlled trial comparing olsalazine and sulphasalazine for maintenance treatment of ulcerative colitis. Scand ] Gastroenterol 1988;148 (Suppl):45-7.

20. Riley SA, Mani V, Goodman MJ, Herd ME, Dutt S, Turnberg LA. Comparison of delayed-release 5-aminosalicylic acid (mesalazine) and sulphasalazine as maintenance treatment for patients with ulcerative colitis. Gastroenterology 1988;94:1383-9.

21. Rutgeerts $P$, International Study Group. Comparative efficacy of coated, oral 5-aminosalicylic acid (Claversal) and sulphasalazine for maintaining remission of ulcerative colitis. Aliment Pharmacol Therap 1989;3:183-91.

22. Andreoli A, Cosintino R, Trotti R, Berri F, Prantera C. 5-aminosalicyclic-acid (5-ASA) vs salazyopyrin (SASP) in the oral treatment of active ulcerative colitis (UC) and in remission. Presented at: Clinical Controversies in Inflammatory Bowel Disease, Bologna 1987:170. (Abst)

23. Gionchetti P, Campieri M, Belluzzi A, et al. Pentasa in maintenance treatment of ulcerative colitis. Gastroenterology 1990;98:251. (Lett)

24. Porro GB, Ardizzone S, Fasoli R, Petrillo M, Desideri S. Comparison of mesalazine with sulphasalazine in prophylactic effects treatment of ulcerative colitis. Gut 1989;30:A1467. (Abst)

25. Kiilerich S, Ladefoged K, Rannem T, Ranlov PJ, Danish Olsalazine Study Group. Prophylactic effects of olsalazine versus sulphasalazine during 12 months maintenance treatment of ulcerative colitis. Gut 1992;33:252-5.

26. Rijk MC, van Lier HJ, van Tongeren $\mathrm{JH}$. Relapse-preventing effect and safety of sulphasalazine and olsalazine in patients with ulcerative colitis in remission: A prospective double-blind, randomized multicentre study. Am ] Gastroenterol 1992;87:438-42.

27. Campieri M, Lanfranchi GA, Bazzocchi G, et al. Treatment of ulcerative colitis with high-dose 5-aminosalicylic acid enemas. Lancet 1981:ii:270-1.

28. Danish 5-ASA Group. Topical 5 -aminosalicylic acid versus prednisolone in ulcerative proctosigmoiditis. Dig Dis Sci 1987;32:598-602.

29. Sutherland LR, Martin F, Greer S, et al. 5-Aminosalicylic acid enema in the treatment of distal ulcerative colitis, proctosigmoiditis, and proctitis. Gastroenterology 1987;92:1894-8.

30. Biddle WL, Miner PB. Long-term use of mesalamine enemas to induce remission in ulcerative colitis. Gastroenterology 1990;99:113-8.

31. Williams CN, Haber G, Aquino JA. Double-blind, placebo-controlled evaluation of 5-ASA suppositories in active distal proctitis and measurement of extent of spread using ${ }^{99 \mathrm{~m}} \mathrm{Tc}$-labeled 5-ASA suppositories. Dig Dis Sci 1987;32(Suppl):71S-5S.

32. Van Hogezand RA, Van Hees PAM, Van Gorp JPWM, et al. Double-blind comparison of 5-aminosalicylic acid and acetyl-5-aminosalicylic acid suppositories in patients with idiopathic proctitis. Aliment Pharmacol Therap 1988;2:33-40.

33. Campieri M, Gionchetti P, Belluzzi A, 
et al. 5-aminosalicylic acid as enemas or suppositories in distal ulcerative colitis. J Clin Gastroenterol 1988;10:406-9.

34. Sutherland LR, Martin F. 5 -aminosalicylic acid enemas in the maintenance of remission in distal ulcerative colitis and proctitis. Can J Gastroenterol 1987;1:3-6.

35. Biddle WL, Greenberger NJ, Swan JT, McPhee MS, Miner PB Jr.

5-aminosalicylic acid enemas: Effective agent in maintaining remission in left-sided ulcerative colitis.

Gastroenterology 1988;94:1075-9.

36. D'Albasio G, Trallori G, Ghetti A, et al. Intermittent therapy with high-dose 5-aminosalicylic acid enemas for maintaining remission in ulcerative proctosigmoiditis. Dis Colon Rectum 1990;33:394-7.

37. D'Arienzo A, Panarese A, D'Armiento FP, et al. 5-Aminosalicylic acid suppositories in the maintenance of remission in idiopathic proctitis or proctosigmoiditis: A double-blind placebo controlled clinical trial. Am J Gastroenterol 1990;85:1079-82.

38. Dickinson RJ, King A, Wight DGD, Hunter JO, Neale G. Is continuous sulphasalzine necessary in the management of patients with ulcera- tive colitis? Results of a preliminary study. Dis Colon Rectum 1985;28:929-30.

39. Truelove SC. Treatment of ulcerative colitis with local hydrocortisone hemisuccinate sodium: A report on a controlled therapeutic trial. Br Med J 1958;2:1072-7.

40. Truelove SC, Witts LJ. Cortisone and corticotrophin in ulcerative colitis. Br Med J 1959;i:387-94.

41. Lennard-Jones JE, Misiewicz JJ, Connell AM, Baron JH, Jones FA. Prednisone as maintenance treatment for ulcerative colitis in remission. Lancet 1965;i:188-9.

42. Powell-Tuck J, Parkins RA. A controlled trial of alternate day prednisolone as a maintenance treatment for ulcerative colitis in remission. Digestion 1981;22:263-70.

43. Jewell DP, Truelove SC. Azathioprine in ulcerative colitis: Final report on controlled therapeutic trial. Br Med J 1974:4:627-30.

44. Hawthorne AB, Logan RFA, Hawkey CJ, et al. Efficacy of azathioprine in maintaining remission in ulcerative colitis: A placebo-controlled withdrawal trial. Gastroenterology 1991;100:A216. (Abst)

45. Gilat T, Leichtman G, Delpre G,
Eshchar J, Bar Meir S, Fireman Z. A comparison of metronidazole and sulphasalazine in the maintenance of remission in patients with ulcerative colitis. J Clin Gastroenterol 1989;11:392-5.

46. Whorwell PJ, Whorewell GM, Bamforth J, et al. A double-blind controlled trial of the effect of sodium cromoglycate in preventing relapse in ulcerative colitis. Postgraduate Med J 1981;57:436-8.

47. Hermanowicz A, Sliwinski Z, Nowak A, Gajos L. The effect of levamisole on the maintenance of remission of ulcerative colitis. Scand J Gastroenterol 1987;22:367-71.

48. Truelove SC, Witts LJ. Cortisone in ulcerative colitis: Final report on a therapeutic trial. Br Med J 1955;4947:1041-8.

49. Gilat T, Suissa A, Leitchtman G, et al. A comparative study of metronidazole and sulphasalazine in active, not severe, ulcerative colitis. An Israeli multicentre trial. J Clin Gastroenterol 1987;9:415-7.

50. Chapman RW, Selby SW, Jewell DP. Controlled trial of intravenous metronidazole as an adjunct to corticosteroids in severe ulcerative colitis. Gut 1986;27:1210-2. 


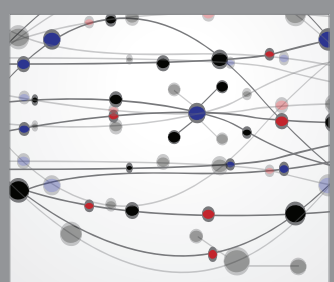

The Scientific World Journal
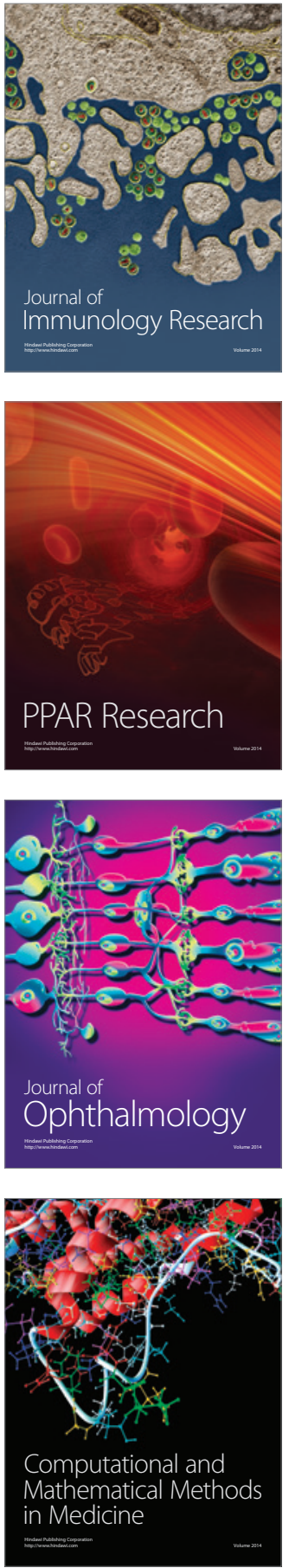

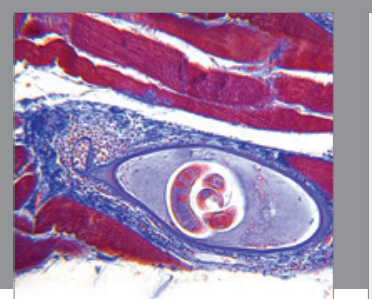

Gastroenterology Research and Practice

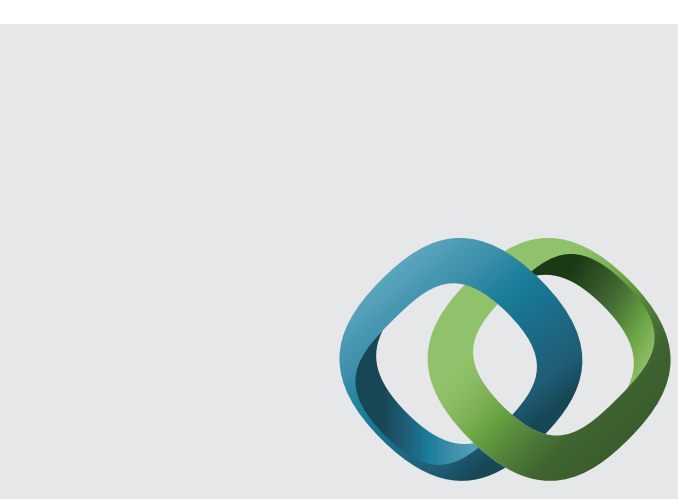

\section{Hindawi}

Submit your manuscripts at

http://www.hindawi.com
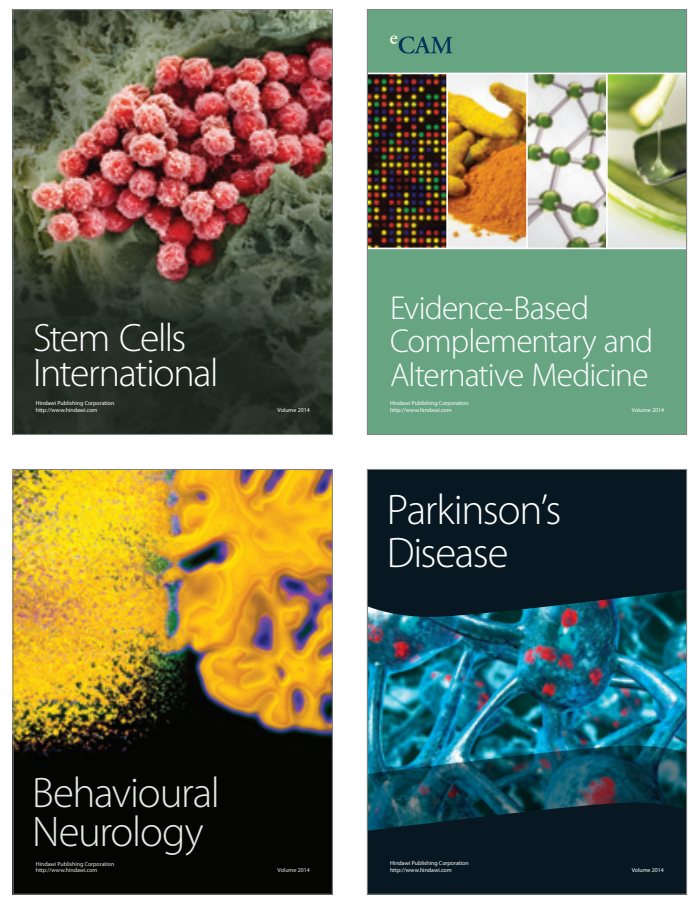
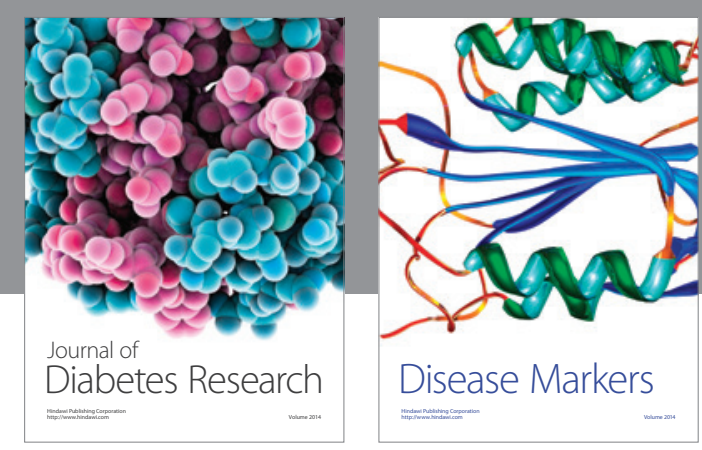

Disease Markers
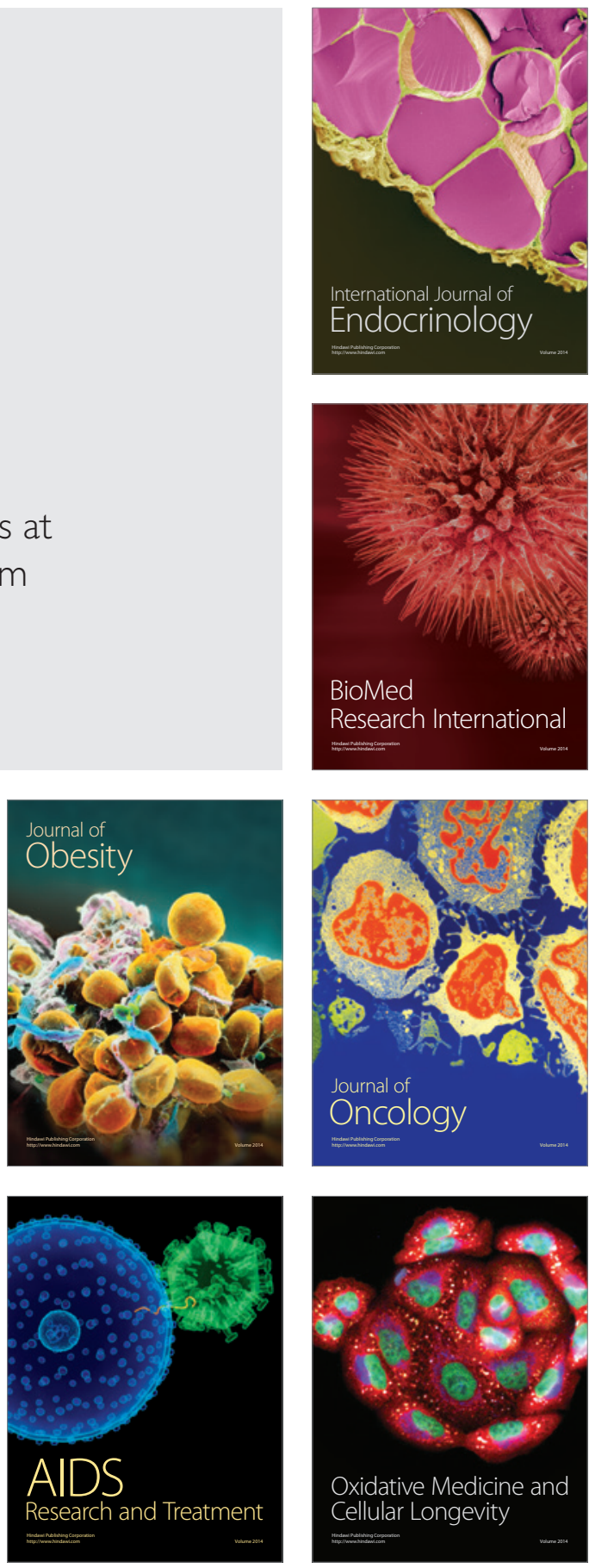